\title{
PROFESINIŲ DEFORMACIJŲ SOCIOKULTŪRINIŲ VEIKSNIŲ RAIŠKOS KONTEKSTAI
}

\author{
Audronė Juodaitytė, Daiva Malinauskienė \\ Šiauliu universitetas
}

\begin{abstract}
Anotacija
Straipsnyje atskleidžiami veiklos profesionalizacijos procesų genezès sociokultūriniai kontekstai specialumas vs universalumas paradigmose. Atsižvelgiant ị šiuolaikinės vartotojų visuomenès sąlygas, apibūdinamas stiprèjantis profesinès veiklos specializavimasis žmogus - žmogus srityje, kuriai priklauso ir medicinos darbuotojo profesija. Išanalizavus profesinès specializacijos pasekmes medicinos darbuotojo veiklos pasaulèžiūros nuostatoms, per jo individualybès raišką gilinamasi i profesinių deformacijų vertybinius ir dvasinius reiškinius medicinos darbuotojas - pacientas santykių kontekste. Viena vertus, žvelgiama į medicinos darbuotojo profesijos misionierišką paskirtị, kita vertus, $-\mathrm{i}$ individualaus profesinio augimo galimybes. Kontekstualizuojant profesinès veiklos ir asmenybès deformacijų pobūdị, pasitelkiamas fenomenologinis požiūris ị profesinės veiklos pasaulị, patirčių ịprasminimo galimybes per jų pažinimą ir esmès suvokimą.

PAGRINDINIAI ŽODŽIAI: sociokultūriniai kontekstai, profesinès veiklos specializacija, profesinès veiklos deformacijos.
\end{abstract}

\begin{abstract}
The article examines sociocultural contexts of the genesis of the processes of the professionalization of performance within the paradigm of specificity $v s$ generality. It emphasizes the increasing specialization in the area of human-human interactions inherent in the medical profession that are pertinent to the conditions of modern consumer society. The authors analyze the consequences of professional specialization in relation to the shifting physicians' worldview and through individual self-expression explore professional deformations associated with moral and spiritual phenomena within the context of doctor-patient interactions that, on the one hand, are oriented towards missionary nature of the medical profession and, on the other, towards the opportunities of individual professional development. In the examination of occupational continuum, the authors utilize a phenomenological approach that enables to characterize different aspects of professional and personal deformations, as well as to analyze the meaning of professional opportunities through recognition and comprehension of their essence.

KEYWORDS: sociocultural contexts, specialization of professional performance, deformations of professional performance.
\end{abstract}

\section{Ivadas}

Žmogus, specializuodamasis kurioje nors profesinès veiklos srityje, gali save išreikšti dvejopai: būti arba aktyvus, arba pasyvus jos dalyvis. Pirmuoju atveju specialistas ịsitraukia ị asmeninę sąveiką su profesinès veiklos pasaulio įvairove, antruoju - jis tokių galimybių netenka. Tačiau profesinė specializacija, jos subjektui laikantis ir aktyvios, ir pasyvios pozicijos, susiaurina asmenybès individualu- 
mo raišką. Todèl, jeigu profesinejje veikloje specialistas apsiriboja instrumentinès veiklos pozicija, jis negali suvokti socialinio, kultūrinio konteksto, kuris iš esmès yra vertybinis. Žmogaus, kaip aktyvaus socialinio dalyvio, atskyrimas nuo profesinès veiklos subjekto, sudaro pagrindą profesinėms deformacijoms. Šis reiškinys aiškinamas tuo, kad specialistas praranda profesinès veiklos pasauli kuriančio individo vaidmenị. Be to, orientacija tik ị veiklos pasaulio išskirtinumo / specifiškumo suvokimą išeliminuoja sąveiką su šio pasaulio universalumu (Driver, 2006; MacIntyre, 1998). Žmogaus gyvenamają erdvę išskyrus ị kasdienio gyvenimo ir profesinès veiklos sritis, galima įžvelgti neatitikimą tarp žmogaus, kaip kūrybiškos ir profesionalios individualybės, ir žmogaus, kaip profesinès veiklos instrumento (Simmel, 2004; Bauman, 2011).

Visose profesinès veiklos srityse, ypač tokiose kaip žmogus - žmogus, gali egzistuoti ir subjektiniai, ir objektiniai specialisto santykiai su materialiaisiais ištekliais, aparatūra, medžiagomis, žmogumi. Tai vyksta dẻl darbo išteklių sampratos susiaurinimo, nes materialieji ištekliai dažnai tapatinami su žmogiškaisiais (Bauman, 2011; Mickūnas, Jonkus, 2014). Profesinę deformaciją, kuriai priklauso ir subjektinių (asmenybinių) santykių su darbo sritimi nuvertinimas, lemia specialisto saviraiškos stoka (MacIntyre, 1998; Driver, 2006). Vidiniai žmogaus ištekliai (anatominiai, fiziologiniai, biologiniai ir kt.) nèra beribiai, todèl ir pavienis individas negali būti geras kelių profesijų specialistas, nes jam neužteks kognityvinių bei fizinių jègų, kurių reikalauja šiuolaikinè specializacija. Tai reiškia, kad specialistas turi turèti universalių žinių apie giminingas šiuolaikinès veiklos specializacijas ir, remdamasis universaliu išprusimu, specializuotis vienoje iš jų. Siekdamas atitikti profesinius reikalavimus, turi įsitraukti ị profesinių žinių kaupimo ir atitinkamų savybių ugdymosi procesus. Tačiau, kaip teigia L. Cvetkova (Цветкова, 1994), profesionalizacijos esmès ir ribotumo suvokimas yra tarpusavyje susiję reiškiniai. Mokslininkè įrodinėja, kad profesionalas, kaip subjektas, nepajègus laiko rėmuose įsigilinti ị veiklos subjektą (žmogų), atsižvelgdamas ị visų jo ryšių ir santykių su pasauliu įvairovę. Specialistui dažnai tenka žvelgti ị žmogų tik kaip ị savo profesinių interesų objektą, nes kiekvienoje profesinėje veikloje žmogus gali sèkmingai veikti tik apsibrezžęs konkretų savo veiklos lauką (MacIntyre, 1998; Thornton, 1992). R. Konečnij, N. Bouchal (Конечный, Боухал, 1983) aiškina, kad kiekvienas gydytojas gali tapti tik tam tikros srities profesionalu, nes tik taip jis gali užtikrinti diagnozės tikslumą ir gydymo sẻkmingumą. Tačiau būtent čia ir slypi pavojai, keliantys profesinę deformaciją: suprantant savo veiklą tik kaip specializuotą, prarandamos tos veiklos vertybinès orientacijos ir skurdinama santykių žmogus - žmogus sritis (Wulff, Pedersen, Rosenberg, 2001).

Taigi profesionalizacija vienoje srityje neleidžia perimti žmonijos sukauptos patirties daugiaprasmėje santykių srityje žmogus - žmogus. Tada tampa ịmanomi 
tik dalykiniai specialisto santykiai su savo veiklos subjektu. Nūdienos sąlygomis nyksta ir pastarieji, nes sveikatos apsaugos srityje visiškai įdiegus e-sistemą, santykiai tarp paciento ir gydytojo taps tik nuotoliniai - virtualūs. Todèl ypač aktuali tampa H. Brody (1981) nuomonè, kad medicinos darbuotojo, kaip specialisto, veikloje svarbią vietą pradeda užimti tik duomenų apie ligą rinkimas, nepuoselëjant reikiamo santykio su pacientu. Formalaus santykio su pacientu galima būtų išvengti, jeigu būtų siekiama jo pasitenkinimo teikiama paslauga vertybine prasme. O tam reikia naujų sąveikos pacientas - medicinos darbuotojas formų. Kaip teigia R. Konečnij, N. Bouchal (Конечный, Боухал, 1983), profesionalas turi atlikti ne tik instrumentinès veiklos funkcijas, bet ir turèti šiai veiklai būtinų pasaulèžiūros nuostatų, apimančių vertybes bei jų raišką, ypač santykių ir jausmų su pacientu srityse.

Nors profesinès veiklos etiniai, vertybiniai ir instrumentiniai veiksniai socialiniuose-humanitariniuose moksluose dažniausia tiriami orientuojantis ị jų raiškos universalumą profesijų pasaulyje, tačiau šių veiksnių raiškos pobūdis ne visada siejamas su konkrečia profesinès veiklos sritimi ir jos specifiką atskleidžiančius vertybinius instrumentinius kontekstus. Šių kontekstų sąveika gali būti apibūdinama specialumas $v s$ universalumas sociokultūrinèje paradigmoje. Išryškejja socialinio, filosofinio jų sąveikos pagrindimo būtinumas, pasitelkiant konkrečios profesijos atvejo analizę.

Problema: kaip konceptualizuoti medicinos darbuotojų profesinių deformacijų raiškos socialinị-kultūrinị lauką, remiantis ontologine ir fenomenologine prieiga.

Objektas - profesinių deformacijų sociokultūriniai kontekstai.

Tikslas: konceptualizuoti profesinès veiklos vertybinị-emocinị lauką bei, pasitelkus medicinos darbuotojų / gydytojų atvejị, išryškinti profesinių deformacijų raišką, remiantis ontologine, fenomenologine prieiga, kuria remiantis galima suprasti profesinių deformacijų reiškinius.

Tyrimo metodai: mokslinès literatūros analizè, metaanalizè, atvejo analizè.

\section{Fenomenologinio požiūrio raiška profesinių deformacijų prasminiuose kontekstuose}

Fenomenologai (Husserl, 1952; Heidegger, 1998; Mickūnas, Jonkus, 2014) fenomenologinio požiūrio esmę apibrèžia suteikdami jam kasdienio gyvenimo suformuotų ir žmoguje slypinčių įsitikinimų, nuovokų turinị. Jie teigia, kad turinys nepriklauso nuo veiklos objekto prigimties. Vaizdiniai sąveikauja su aplinka, jos prasminiu suvokimu ir veikia patị žmogų bei lemia jo santykius su visa gyvenamaja aplinka. Mūsų sąmonèje susiformavę vaizdiniai, fiksuojantys įvairius veiklos 
pasaulio reiškinius, suponuoja jų, kaip objektų, esmės supratimą būtent tokia forma, kuri žmogaus suvokiama per jo ịsitikinimus. Tada tai, kas savaime suprantama, tampa nuostata, kad pavienis žmogus gali būti aplinkinio pasaulio subjektu, sąveikaujančiu su jo reiškiniais ar daiktais.

Filosofai (Adorno, 2001; Gadamer, 1989) analizuoja žmogaus darbinès veiklos diferencijavimo(si) procesą kaip deformacijų veiksnį, kuriam ịvairiais žmogaus civilizacijos laikotarpiais būdinga istorinè, kultūrinè genezè. Profesinès veiklos diferencijavimas(is) - žmonijos civilizacijos požymis. Tačiau šiame reiškinyje slypi tam tikrų prieštaravimų. Visų pirma veiklos diferencijavimas(is) neigiamai veikia pati veiklos individą: dehumanizuoja jị kaip asmenybę ir jo santykius su kitais žmonèmis. A. Mickūnas (2014) tyrinèja du prieštaringus procesus: profesinès veiklos specializavimo(si) ir universalizavimo(si) reiškinius bei dèl to atsiradusius žmogaus prasminius požiūrius ị save ir veiklą.

Sociologijos atstovai (Bourdieu, 2003; Giddens, 1982) mano, kad ankstyvoji profesionalizacija suponavo sudètingą darbinès veiklos diferencijavimo(si) sistemą, kuri egzistuoja ir šiandien. Atskyrus protinị darbą nuo fizinio, vienos profesijos tapo socialiai privilegijuotos, o kitos - antrarūšès. Profesijų diferencijavimas buvo institucionalizuotas ir įstatymų. Pradètos taikyti mažiau prestižinès darbo formos, kurios tapo neigiamu profesinès veiklos motyvatoriumi. I P.| Thornton (1992) keliamą klausimą, ar gali profesijos prestižas tapti profesinès deformacijos pagrindu, galima būtu atsakyti hipotetiškai: kuo aukštesnis profesijos prestižas, tuo mažesnis pagrindas profesinès veiklos pasaulio deformacijai. Tačiau tai nèra tiesa. F. Regnier ir J. Rouzioux (1983) nuomone, šị reiškinị lemia kultūrinės, profesinès saviraiškos normos, ipareigojančios gerbti ir vertinti kiekvienos profesijos atstovą. Todèl Vakarų civilizacijos seniai atsisakè prievartinio darbo, kaip bausmès ar perauklèjimo priemonès (Foucault, 1998). Prievartinis ir dirbtinis kai kurių profesijų paskelbimas prestižinėmis lemia iškreiptas profesines orientacijas ir apsisprendimą kokybiškai veiklai. Priklausomybė vienai ar kitai profesijai individui reiškia ir priklausomybę tam tikrai profesinei grupei, kuri riboja jo veiklą specifinėmis funkcijomis. Todèl bet kurios profesinès veiklos socialinio lygiavertiškumo pripažinimas kartais prieštarauja ekonominiam požiūriui, nes pavienis žmogus profesinių veiklų sistemoje tampa mažiau ekonomiškai naudingas.

Platonas (1981), pirmasis suformulavęs darnaus darbo ịvairovès dėsningumą, manè, kad, kuo ilgiau žmogus specializuojasi konkrečioje veikloje, tuo daugiau jis turi tos veiklos patirties. Tačiau civilizacija paneige Platono idėją - profesinès veiklos trukmè nèra pagrindinis žmogaus profesinès veiklos efektyvumo veiksnys. Tam ịtakos turi ir kiti socialiniai, politiniai, kultūriniai veiksniai. Todèl kai kuriose dabartinèse visuomenèse profesinès veiklos turinį rekomenduojama keisti kas 
keleri metai. G. Simmel (2004) suformulavo profesinès veiklos kaitos principą ir manè, kad tai gali išgelbèti žmogų nuo profesinès specializacijos rutinos.

E. Durkheim (2001) pasiūlè pozityvistinio pobūdžio teiginị visuomeninio gyvenimo analizei: ne stengtis priešpriešinti, o ieškoti solidarumo. Akcentuodamas amoralias darbų skirstymo ị protinius ir fizinius pasekmes, minètas mokslininkas pastebi, kad ši pozicija lemia konkurenciją, diskriminaciją, darbo rutiniškumą, todèl profesionalų grupèse ịžvelgia moralinę jègą, galinčią žmones apsaugoti nuo individualaus egoizmo, be to, skatina atkreipti dèmesị i profesinę etiką, kuri garantuotų darbuotojų profesinị sąžiningumą. E. Durkheim (2001) atmetė moralinę diletantizmo reikšmę ir, teigdamas, kad vis labiau išryškèja darbo paskirstymo principas, nes progresuoja ne tik amatininkiškumas, bet ir profesionalumas, iškèlè svarbų socialinị klausimą apie profesinio darbo skirstymo pasekmes - individualybès praradimą.

F. W. Taylor (2010), profesijas skyręs ị dvi grupes - vadovų ir vykdytojų, teigè, kad pirmieji turi norèti ir gebèti vadovauti, o antrieji - sąžiningai dirbti jų vadovaujami. Jo nuomone, abu šie profesinès veiklos skirstymo veiksniai ypač sąveikauja tose srityse, kuriose sunku kontroliuoti veiklos procesus, rezultatus, normas ir taisykles. Teigiama, kad šiuo atveju efektyviausiai veikia principas, jog sąžinè - geriausias kontrolierius.

Klasikiné filosofijos krizė lèmè, kad filosofija prarado mokslus susiejančio koordinatoriaus vaidmenị ir ịgijo kitą misiją - tapo tarpininku tarp mokslų. Dèl to paskiri mokslai turejo suformuoti tiriamos srities filosofiją, kuriai reikejo specialaus mokslinio pagrindimo. Todèl ịvairios praktikos rūšys ir žmonių veikla pareikalavo ivvairių mokslų žinių, nes kiekviena praktinè-profesinė veikla yra sintezuojančio pobūdžio. Šiai sričiai priklauso ir profesinès veiklos metodologija, kuriai būdingas savitas profesinio mąstymo tipas. Vis didejjanti profesinès veiklos diferenciacija nebeišsitenka „naujojo mąstymo“ metodologijoje, kai lig šiol vyravusios normos, instrumentai atmetami iš dalies arba visiškai (Rubavičius, 2010). Todèl pastebimai ima konfliktuoti du prieštaringi reiškiniai, apimantys ir profesinès veiklos skirstymą ị dvi sritis - protinę ir fizinę, t. y. valdymą ir atlikimą. Toks skirstymas reiškia ir pavienio žmogaus potencialo bei jo veiklos ištekliu ribotumo pripažinimą, kartu lemia asmenybès profesinių deformacijų atsiradimą.

E. Artemjeva ir J. Viatkin (Артемьева, Вятькин, 1965), tyrinejję subjektyvų profesijų pasauli, teigia, kad profesionalai, vertinantys savo profesiją kaip gyvenimo būdą, turi ypatingą požiūrị ị pasauli ir atitinkamai keičia santykị su jo reiškiniais bei objektais. Todèl, mokslininkų teigimu, egzistuoja semantinès pasaulio ypatybès: prasmės ir reikšmės. Ir tai yra priežastis, dèl ko reiškiasi ir kita profesionalo pasaulio ypatybė - konceptualizuotų veiklos supratimo modelių, kuriuos žmogus susiformuoja darbo procese, ilgalaikiškumas. R. Konečnij, N. Bouchal 
(Конечный, Боухал, 1983) teigimu, egzistuoja vidiniai profesionalo pasauliai, vienus kurių galima vadinti atvirais, kitus - uždarais, nes pašaliniam stebėtojui sunku visa tai apibūdinti. Profesionalas savo veikloje kasdien remiasi įspūdžiais, kurie tampa praktinès veiklos apmąstymų medžiaga. G Ščedrovickij (Щедровицкий, 1995), nagrinėdamas profesionalo požiūrị ị aplinką, teigè, kad kiekviena profesija stengiasi asimiliuoti ypatingą profesinį mąstymą, kuris išreiškia ir naują požiūrị ị profesinès veiklos vertybes bei procesus. Jo nuomone, būtent pasaulèžiūros profesionalizacija ir lemia asmenybès profesines deformacijas. Pasaulèžiūra - tai gebẻjimas atitinkamai žvelgti ị veiklos kasdienybę, susidaryti veiklos ir vertybių sistemos vaizdinius. Mokslininkas aiškina, kad pasaulěžiūros sąveika su siauru aplinkos pažinimu ir tam tikromis jo aspektacijomis profesionalą tarsi supančioja, todèl jis tampa nepajègus tą aplinką keisti.

F. Regnier, J. Rouzioux (1983), tyrinejję profesinį mąstymą ir profesinès veiklos įtaką žmogui, nurodè, kad profesinis vaidmuo asmenybę veikia ịvairiapusiškai: kelia žmogui tam tikrų reikalavimų, kuriuos šis perkelia ị realią tikrovę, kartu perkeldamas profesini mąstymą ir profesinio bendravimo stilių. Tada profesinė elgsena tampa neadekvati situacijai. Ypač tai pavojinga prestižinių specialybių atstovams ir žmonėms, kurių profesinè veikla asmeniškai svarbi jiems patiems. Profesinio vaidmens ịsitvirtinimas turi ịtakos individualioms veiklos nuostatoms, vertybinėms orientacijoms, santykiams su kitais. P. Thornton (1992) nuomone, žmogus tampa ịsisąmoninto profesinio vaidmens įkaitu. Nukrypimai nuo realaus pasaulio adekvataus suvokimo dar labiau didina profesines deformacijas, kurias lydi automatizuoti aplinkos vertinimo stereotipai. Tai priklauso nuo žmogaus savivertès ir gebėjimo kritiškai vertinti savo įsitikinimus, pažiūras, laiku jas koreguoti. Priešingu atveju laikomasi nuostatos, kad naujos žinios trukdo efektyviai ir sèkmingai veikti, kas tampa trukdžiu priimti profesinius sprendimus naujose veiklos situacijose. Kaip pastebi P. Thornton (1992), tai ypač būdinga mokytojams ir gydytojams, nes kiekvieną atvejį šiu profesijų žmonès suvokia kaip tipišką, jau pasitaikiusį praktinejje veikloje. F. Regnier, J. Rouzioux (1983) formuluoja išvadą: ilgalaikèje profesinèje / darbinèje veikloje susiformuoja profesinis asmenybès tipas, kuris lemia profesines deformacijas.

Profesinès asmenybès deformacijos savo modalumu ir kryptingumu skiriasi: joms būdingos teigiamos ir neigiamos charakteristikos. Viena vertus, pozityvi profesinès veiklos įtaka asmenybei reiškia atsakingą požiūrị ị darbą, sukauptą patirtị, nuolatinị žinių gilinimą ir naujų žinių siekimą, kūrybą. Kita vertus, ilgalaikis profesinis vaidmuo specialisto asmenybę gali veikti neigiamai: susiformuoja ritualizuotas požiūris ị veiklą, perdetas didaktizmas, emocinis nejautrumas, ịsakmus bendravimo tonas. Tai ypač pavojinga žmogus - žmogus profesijų atstovams, nes būtent ši sritis numato individualią ypatybiu raišką, subtilų santykị su aplinka ir 
veiklos situacijomis, ị kurias šios srities darbuotojai dažnai patenka. Ypač tai aktualu gydytojo profesijai, kur egzistuoja ligonio praradimo reiškinys, kai gydantis gydytojas neįžvelgia paciento individualių ypatybių (Regnier, Rouzioux, 1983). Tokiu atveju ligonio asmenybès pažinimas užgožiamas ịvairių duomenų apie ligą rinkimu ir pagrindinis gydytojo veiklos bruožas gydytojas - ligonis transformuojasi ị gydytojas - aparatūra-ligonis.

\section{Medicinos darbuotojų profesinès deformacijos raiškos požymiai}

Skirtingai nei kitų profesijų atstovai, medicinos darbuotojai, nepaisant jų tarnybinès padèties, susiduria su skirtingo amžiaus, lyties, tautybės, socialinio-ekonominio statuso žmonėmis. Taigi medicinos darbuotojai turi išmanyti profesinės komunikacijos kultūrą. Tam reikia ir specialių psichologinių žinių, ir universalių bendravimo ịūdžių. Tad mokslininkus ir tyrëjus domina medicinos darbuotoju profesinès veiklos specifika (Regnier, Rouzioux, 1983; Thornton, 1992; Brody, 1981; Лещинский, 1989).

Tyrinėdami gydytojų profesinės deformacijos veiksnius kai kurie mokslininkai (Brody 1981; Jasulaitis 1996; Лещинский 1989 ir kt.) ypatingą dėmesị skyré tokiam reiškiniui, kaip prietaisų fetišizavimas, kuris lemia pacientų nuasmeninimą, anamnezès klinikos ir pacientų asmenybės ypatybių nuvertinimą. H. Brody (1981) nuomone, šią problemą lemia siaura gydytojo specializacija ir bendrakultūrinio pa(si)rengimo stoka. J. Driver (2006) nurodo neigiamas šio reiškinio pasekmes: siauras mąstymas, subjektyvi diagnozė, biologinių duomenų pervertinimas ir psichologinių ligos veiksnių nepaisymas. Viso to pasekmè - gydytojo dèmesio sutelkimas ties vienu paciento organu, o ne ties žmogaus organizmo visuma. Kaip teigia J. Driver (2006), dèl šios priežasties atsiranda profesinio mąstymo, veiklos, gydytojo misijos ir pašaukimo supratimo deformacijų. Tada gydytojų darbe reiškiasi individualaus ir visuminio požiūrio ị pacientą stoka, kuri neleidžia skleistis gerumui, švelnumui ir meilei. F. Konečnij, J. Bouchal (Конечный, Боухал, 1983) nuomone, neretai gydytojo elgesys tampa šiurkštus, kyla nepasitenkinimo protrūkių, nesilaikoma etikos, paciento ligą aptarinèjant su kolegomis. Tokie neprofesionalios veiklos požymiai gali dar labiau kenkti paciento sveikatai.

Profesinès deformacijos požymis yra ir tam tikras profesinis žargonizmas (Конечный, Боухал, 1983). Mokslininkų teigimu, gydytojų profesinès veiklos žargonas yra profesinès deformacijos požymis, todèl gydytojai neturètų ligoniams klijuoti etikečiu pagal jų ligos pobūdị (astmatikai, skrandininkai, reumatikai ir kt.). Jie pastebi ryši tarp gydytojo profesinès kvalifikacijos ir bendravimo su ligoniu stiliaus: kuo žemesne gydytojo kvalifikacija, tuo mažiau jis bendrauja su ligoniu, labiau pasitiki diagnostinių aparatų duomenimis. Nūdienos sąlygomis 
dėmesio stoka pacientams lemia gydytojo pašaukimo ir misijos prasmės nuvertinimą (Jakušovaite, 2001). Vietoj pagalbos ir atjautos ligonis patiria visišką jo psichinès situacijos atmetimą. L. Cvetkova (Цветкова, 1994), analizavusi greitosios pagalbos medikų elgesị su pacientais, nustate, kad kai kurie jų turi psichinio nestabilumo ir neigiamo požiūrio ị pacientus bruožų. Mokslininkè nurodo bendruosius profesinès deformacijos požymius: prarastas gydytojo profesijos ir sąžinès pojūtis, technokratinis mąstymas, kai ị žmogų žvelgiama kaip ị biologinę būtybę, o ị ligą - kaip ị gedimą, kurị galima pašalinti vaistais arba operacija. Gydytojo profesinès deformacijos reiškiniams L. Cvetkova (Цветкова, 1994) priskiria ir patocentrizmo nuostatas. Tai toks mąstymo būdas, kai susitelkiama ties ligos (patos), o ne ties sveikatos (sanos) supratimu. Ji teigia, kad individualizuoto požiūrio ị ligonị ir jo gydymą stoka eliminuoja individualią gydytojo atsakomybę už konkretų ligonị. Tada pastebima moralinio paciento palaikymo ir gailestingumo stoka. Tai sudaro sąlygas biurokratizmui ir kyšininkavimui, nes ligonis siekia asmeninio dèmesio, bendravimo. Todèl tyrèja siūlo gydytojams vadovautis psichosomatiniu požiūriu ị pacientą, atsižvelgti i jo emocijas ir asmenybinius ligos etiologijos veiksnius.

L. Cvetkova (Цветкова, 1994), tyrusi gydytojo ir paciento komunikacijos procesus, nustatè, kad nesėkmes patiriantiems gydytojams būdingi šie požymiai: žemas empatijos lygis, neišsivystęs požiūris ị kitą žmogų, kaip vertybę, paciento psichinès būsenos ignoravimas, neigiamas požiūris ị paciento aktyvų domėjimąsi liga, draugiškumo ir pasirengimo teikti pagalbą stoka.

S. Kripper (Криппер, 1994) nurodo, kad šiuolaikinè medicina nepakankamai dẻmesio skiria senyvo amžiaus žmonių konsultavimui, t. y. jų emocinėms, socialinėms ir dvasinėms problemoms. Dauguma praktikuojančių gydytojų miglotai supranta kultūrinius šių pacientų bruožus, todèl dažnai tampa bejègiais, kai pacientas jiems užduoda klausimą apie gyvenimo prasmę arba mirtị. Mokslininko nuomone, kuo labiau senyvo amžiaus žmogui reikia pagalbos, tuo dažniau jis pateikia panašių klausimų. Tačiau toks ligonis dažnai patenka ị paradoksalią situaciją: jam sunku surasti profesionalą, kuris galètų padèti pacientui, kai jị kamuoja dvasinès problemos dèl ligos. Mokslininkas teigia, kad dažna gydytojų nuomonè, jog dvasinis pacientų palaikymas - ne kūno ligų specialistų kompetencija.

Medicinos darbuotojų profesinès etikos deformacijos vis labiau pastebimos, nes ryškèja profesinè specializacija. Todèl dažnai nebesilaikoma požiūrio ị šiu darbuotojų profesinès veiklos vertybinị imperatyvą žmogus - žmogus ir akcentai perkeliami ị ryšį žmogus - technologijos - žmogus. Taip susiaurinama medicinos darbuotojų moralinè atsakomybè, ribojamos profesinio tobulëjimo galimybès. 


\section{Išvados}

1. Žmogaus veiklos profesionalizacija yra ne tik dalykinio, instrumentinio, bet ir kultūrinio pobūdžio reiškinys. Jam būdinga tam tikra istorinè genezè, kurią lydi žmogaus sąveika su darbo (veiklos) pasauliu. Per ją išreiškiamas požiūris ị esminį veiklos pasaulio vertybinị imperatyvą subjektas - objektas. Žmogaus profesionalizacija tik vienoje kurioje nors veiklos srityje nėra baigtinis procesas, išreiškiantis jos santykius su darbo pasauliu apskritai, nes šis pasaulis keičiasi, o žmogaus veikla ne tik specializuojasi, bet ir universalizuojasi.

2. Žmogaus veiklos profesionalizacija socialine, psichologine ir etine prasmėmis yra prieštaringa. Ji rodo tam tikrų žmogaus išteklių (kognityvinių, sociokultūrinių) raiškos ribotumą, nes pasikliaujama normomis ir taisyklèmis. Ilgalaikẻ profesinè specializacija slepia ir kitą pavojų: žmogus ị veiklą, jos procesą dažnai ima žvelgti instrumentiškai, kaip ị gamtos objektą, kuris gali būti pavaldus joje veikiantiems dėsningumams. Tokiu atveju profesinè veikla nesiejama su pasaulèžiūriniais elementais, veiklos ontinėmis prasmèmis. Tai ypač pavojinga tokioje profesinès veiklos srityje kaip žmogus žmogus. Nesigilindamas ị veiklos prasmes šios srities specialistas dažnai praranda ryšį ir su veikla, ir su komunikacinėmis veiklos prasmėmis.

3. Profesinių deformacijų veiklos procese ịvyksta tada, kai žmogus neịsigilina ị patirčių ịvairovę, jų daugiaprasmị, egzistencinị pobūdị ir tampa veikiančiu atlikèju (homo faber), o ne kūrèju (homo creator). Profesinių deformacijų studijos ypač reikšmingos vartojimo visuomenejje, nes žmogaus veikla dažnai dèl per didelès specializacijos netenka aktyvaus, kuriančio potencialo.

4. Šiuolaikinejje visuomeneje profesinès veiklos pasaulis vis labiau užvaldo ir žmogaus kasdienybės pasaulị, todèl profesinès deformacijos transformuojasi, asimiliuodamos žmogaus galimybes aktyviai konstruoti individualų raiškos pasaulį. Taip jos tampa ịprastu sociokultūriniu reiškiniu, persmelkiančiu visą žmogaus pasauli universaliaja prasme. Todẻl ypač reikšminga profesinès specializacijos patirčių ịvairovès sociokultūrinè-vertybinè analizè fenomenologiniu aspektu, nes tada individo patirtis yra subjektinio pažinimo sritis.

5. Profesinès asmenybės ir veiklos deformacijos ypač pavojingos medicinos darbuotojams (gydytojams), nes ị šią profesinę sritị vis labiau skverbiasi informacinès technologijos, lemiančios ligonio praradimo reiškinị, kai specialistas neįžvelgia paciento individualių ypatybių, supaprastina profesinius sprendimus netradicinėse situacijose. Be to, iškraipoma medicinos darbuotojo profesinès veiklos misija, o pati veikla dehumanizuojama. Nukenčia ir 
specialisto komunikacinè sritis, nes joje nelieka individualizuotos sąveikos su ligoniu, jo išgyvenimais.

6. Profesinès deformacijos raiškos sričių pažinimas, kontekstualizuojant jų sociokultūrines, vertybines prasmes ir individualiu, ir profesinès grupès lygiu, igalina suprasti šio proceso giluminius ryšius ir konstruoti žinojimą. Naujų žinių pagrindu galima projektuoti edukacines programas profesinių deformacijų pažinimo srityje.

\section{Literatūra}

Adorno, T. W. (2001). The Culture Industry. London and New York: Routledge.

Bauman, Z. (2011). Vartojamas gyvenimas. Vilnius: Apostrofa.

Bourdieu, P. (2003). Ivadas ị refleksyviaja sociologija. Vilnius: Baltos lankos.

Brody, H. (1981). Ethical Decisions in Medicine. 2nd ed. Boston: Little, Brown and Company.

Dearlove, J., Bate, T., Dearlove, B., Newman, P. (1982). Ignoring the obvious. Doctor's wives as patients. British Medical Journal, Vol. 285, p. 187-189.

Driver, J. (2006). Ethics: the Fundamentals. Malden, MA: Blackwell Publishers.

Durkheim, É. (2001). Sociologijos metodo taisyklès. Vilnius: Vaga.

Foucault, M. (1998). Disciplinuoti ir bausti: kalejimo gimimas. Vilnius: Baltos lankos.

Gadamer, H. G. (1989). Das Erbe Europas. Frankfurt am Main: Suhrkamp.

Giddens, A. (1982). Profiles and Critiques in Social Theory. Cambridge: Cambridge University Press.

Habermas, J. (1981). Theorie des kommunikativen Handelns. 2 Bd. Frankfurt am Main: Suhrkamp.

Heidegger, M. (1998). Ontology - The Hermeneutics of Facticity. Bloomington: Indiana University Press.

Husserl, E. (1952). Ideen zu einer reinen Phänomenologie und phänomenologischen Philosophie II. Husserliana IV. Den Haag: M. Nijhoff.

Jakušovaitė, I. (2001). Medicina ir filosofija. Kaunas: Kauno medicinos universiteto leidykla.

Jasulaitis, A. (1996). Medicinine etika ir deontologija. Vilnius: Vilniaus universitetas.

MacIntyre, A. (1998). Plain Persons and Moral Philosophy: Rules, Virtues and Goods. The MacIntyre Reader. Notre Dame: University of Notre Dame Press.

Mickūnas, A. (2014). Mokykla, mokytojai, mokiniai. Vilnius: Versus Aureus.

Mickūnas, A., Jonkus, D. (2014). Fenomenologiné filosofija ir jos šěsèlis. Vilnius: Baltos lankos.

Platonas. (1981). Valstybe் (vertė J. Dumčius). Vilnius: Mintis.

Regnier, F., Rouzioux, J. M. (198)3. Contemporary aspects of medical ethics in France. Journal of medical ethics, Vol. 9, p. 170-174.

Rubavičius, V. (2010). Postmodernusis kapitalizmas. Kaunas: Kitos knygos.

Simmel, G. (2004). The Philosophy of Money. London: Routledge.

Taylor, F. W. (2010). The Principles of Scientific Management. Nabu Press.

Thornton, P. I. (1992). The relation of coping, appraisal, and burnout in mental health workers. The Journal of Psychology, Vol. 126(3), p. 261-271.

Wittgenstein, L. (1975). Philosophical Remarks. Ed. by R. Rhees. Oxford: Basil Blackwell.

Wulff, H., Pedersen, S., Rosenberg, R. (2001). Medicinos filosofija. Vilnius: Charibdè.

Артемьева, Е. Ю., Вятькин, Ю. Г. (1965). Психологические методы описания профессии. Bопросы психологии, №. 3, p. 127-133.

Конечный, Р., Боухал, Н. (1983). Психология в медицине. Прага: Авиценум.

Криппер, С. (1994). Духовные измерения психотерапии и целительства. Вопросы психологии, №. 6 , p. $118-133$.

Лещинский, Л. А. (1989). Деонтология в практике терапевта. Москва: Медицина.

Цветкова, Л. А. (1994). Коммуникативная компетентность врачей-педиатров. Автореферат диссертации кандидата психологических наук. Санкт-Петербург.

Щедровицкий, Г. П. (1995). Избранные труды. Москва: Школа Культурной Политики. 


\title{
CONTEXTS OF THE MANIFESTATION OF SOCIOCULTURAL FACTORS OF PROFESSIONAL DEFORMATIONS
}

\author{
Audronė Juodaitytė, Daiva Malinauskienė
}

Summary

Professionalization of human activity is a phenomenon not only of occupational, instrumental, but also of cultural character. It is characterized by certain historical genesis followed by human interaction with the continuum of occupation (activity). The attitude towards the essential value imperative of the occupational continuum subject-object is expressed through it. Human professionalization in only one field of certain activity is not a finite process expressing its relation to the occupational continuum in general, because this continuum is changing and human activity is not only getting more specialized but also more universal.

Professionalization of human activity in social, psychological, and also ethical sense is controversial. It shows the limit of the expression of certain human resources (cognitive, sociocultural) because in its process norms and rules are applied. Long-term professional specialization hides another danger as well: a person starts considering activity and its process instrumentally as an object of nature that can be subordinate to the regularities taking place in it. In this case professional activity is not related to the elements of worldview, ontic senses of activity. It is especially dangerous in such a field of professional activity as humanhuman. Without going deeper into the meanings of activity the specialist of this field often loses the connection both with the activity and with communicative meanings of the activity.

Professional deformations in the process of activity occur when a person does not go deep into the variety of experiences, their multifaceted existential character and becomes an acting maker (homo faber), but not a creator (homo creator). Studies of professional deformations are especially important in consumer society because human activity often because of too much deepening specialization loses it active creative potential.

In modern society the occupational continuum is more and more dominating human everyday life, therefore, professional deformations are transforming assimilating person's possibilities to actively construct the individual field of expression. Thus they become an ordinary sociocultural phenomenon transfusing the entire human world in a universal sense. Therefore sociocultural value analysis of the experiences of professional specialization from the phenomenological 
aspect is especially important because in this case individual experience is the area of subject-focused knowledge.

Professional deformations of personality and activity are especially dangerous for medical specialists because information technologies are more and more intruding into this professional field, because of which the phenomenon of losing a patient is being faced. In this case a specialist does not notice patient's individual peculiarities, simplifies professional decisions in non-traditional situations. Moreover, the mission of doctor's professional activity is distorted and the activity itself is dehumanized. The area of specialist's communication especially suffers because individualized interaction with a patient and his/her experiences no longer exists.

Knowing the fields of the manifestation of professional deformations contextualizing their sociocultural value meanings both on the level of individuality and professional group enables to understand the in-depth relations of this process and construct knowledge. On the basis of new knowledge is possible to project educational programmes in the field of knowing professional deformations. 